\title{
HE USE OF CARD GAME AND TOTAL PHYSICAL RESPONSE (TPR) METHOD TO IMPROVE DEAF STUDENTS' ENGLISH ACHIEVEMENT AT SLB-B PERTIWI PONOROGO
}

\author{
Septian Eka Pratiwi, Pryla Rochmawati. \\ Institut Agama Islam Negeri Ponorogo \\ septianekapratiwi@gmail.com
}

\begin{abstract}
Deaf students are having challenge in understanding language especially English language as third language. The difficulty of the students is to understand new vocabulary without the visual media. Besides that, the teacher seldom uses sign language and approaches to every student in teaching-learning process. In order to make students easily in learning English language, Some possible ways should be applied by using card game and one of method by using total physical response (TPR) method. Card game is a tool applied in learning process which helps student to remember new vocabulary by using picture and total physical response (TPR) is teaching method that can be applied to practice student motor activity. This research aimed to improve deaf students' achievement by using card game and total physical response (TPR) on eleventh grade at SLB Pertiwi Ponorogo. In this research, researcher formulated the problems are: 1) How can card game and total physical response (TPR) improve student's activeness in English class at SLB Pertiwi Ponorogo?. 2) How can card game and total physical response (TPR) method improve deaf students' achievement at SLB Pertiwi Ponorogo?. The design of this research was classroom action research. It included two cycles to enrich deaf student English achievement. Each cycle covered four steps: planning, acting, observing and reflecting. The data were collected by observation, interview and documentation and vocabulary test.The result of the research showed that the students improve their achievement in two cycles. Students' activeness improve significantly at 33,33\% to $83,33 \%$ at the second cycle. Furthermore, there is improvement at students' vocabulary mastery $66,67 \%$ first cycle to $100 \%$ at second cycle.Based on result of the research, it can be concluded that the implementation of card game and total physical response ( method can improve student's English achievement.
\end{abstract}

Keyword: Card Game, Total Physical Response (TPR) Method, and Deaf Students' English Achievement.

\section{INTRODUCTION}

Deaf students have difficulties in some skills especially for hearing and interact each other. According to Peter Westwood the degree of hearing loss influences the degree of difficulty the student will have in learning from auditory methods of teaching. A priority goal in the education of all students 
with impaired hearing it to advanced their language and literacy skill as much as possible. ${ }^{1}$

Language is a systematic means of communicating ideas or feelings by the use of conventionalized signs, sounds, gestures, or marks having understood meanings. ${ }^{2}$ Actually, the students use sign language for interaction during learning process in the classroom. In every nation, sign language is developed variously based on the sign used in daily. So, sign language is different based on the grammatical language and vocabulary in every nation.

The teacher uses Indonesian sign language in learning process. He has difficulties in understanding language, especially for deaf students who get deaf since they were born. It supports the prediction that the readers who are deaf and do not speak well will have difficulty reading. ${ }^{3}$ In primary school, the teacher using signs can accelerate the child's understanding. It had been an experience that the flowing movements of sign seem to assist the speech patterns' ${ }^{4}$ It applied in senior high school of SLB to helps students understand the lesson. Sign language has its own grammar, vocabulary, and literature used just as a spoken language. ${ }^{5}$ In Sign language, students who are deaf use expression and body language to construct what they informed. So, sign language as an aid is to improve students skill during the learning process.

Gesture language also helps the teacher to communicate the material of education. The gesture is designed to help the student understand the message. ${ }^{6}$ When it uses by hearing children, we can easily distinguish gestures from words.

The teacher who teaches in SLB has a particular skill for teaching the students, especially in communication language. The classroom is not interesting because of some factors such as teachers seldom use the various method of teaching, besides that teachers have a limitation in using sign language. So, the teacher does not get participation from the students.

Based on the observation at SLB Pertiwi Ponorogo, the researcher found that the students are not interesting in learning the English language because the teacher seldom used visual aid to explain the lesson. Besides that, The teacher usually taught the English lesson by giving the meaning of the word. Besides that, the teachers always give exercises without the explanation of material. It had done the teacher because the teacher has low skill in Indonesia sign language. So, the

1 Peter Westwood, What Teachers Need Know About Teaching Methods(Australia: ACER Press, 2008), 50.

${ }^{2}$ H. Douglas Brown, Principles of Language Learning and Teaching, 5th ed (White Plains, NY:

Pearson Longman, 2007), 6.

${ }^{3}$ Marc Marschack and Praticia Elizabeth Spencer, The Oxford Handbook of Deaf Studies, Language, and Education, Vol.2 (New York : Oxford University Press, 2010), 288.

${ }^{4}$ Jenny Frouded, Making Sense in Sign : A Lifeline for a Deaf Child ( Britain : Cromwell press, Ltd, 2003), 26.

5 Tammy Gallion, Improving Vocabulary Comprehension for Deaf or Hard of Hearing Students (Marshal University Press: Marshal University Scholar, 2016), 12-13.

${ }^{6}$ Arthur M. Glenberg and Michael P. Kaschak."The Body's Contribution To Language". In The Psychology of Learning and Motivation, ed. Brian H. Ross (United Stated of America : Academic Press, 2003), 111. 
student was hard to get what teacher taught. ${ }^{7}$ The observation provides that the teacher who are teaches in SLB have to know the approach during teachinglearning process.

One of the approach in teaching deaf student is giving deaf reader a full and accurate picture of what reading is all about. ${ }^{8}$ It be a practice for deaf student to understand the text themselves. The students also interested about the material of the lesson. So, student can study the material by giving the meaning of the picture.

Based on the interview with an English teacher at SLB Pertiwi Ponorogo, The teacher makes the English test depend on students' grade English skill and their awareness. The aim of the teaching English at SLB is to understand the English language as second language. The curriculum of the special school is 2013 curriculum. The focus of teaching English is help the student to get vocabulary and giving knowledge about the grammar of English Language. ${ }^{9}$

Felder and Solomon assert that the four dimensions of learning style are visual-verbal, active-reflective, sensing-intuitive, sequential-global. ${ }^{10}$ Based on the dimension of the learning style, the teacher have to know how to teach the students. The deaf students as visual-verbal learners because they are loss hearing so they get knowledge from visual media. Besides that, the visual learners remember best what they see pictures, diagrams, flowcharts, timelines, films, and demonstrations. Students who are verbal learners get more out of words written and spoken explanations. ${ }^{11}$ So, the researcher uses picture media in the learning process.

Teachers always use a picture or graphics-whether drawn, taken from books, newspapers, and magazines, or photographs to facilitate learning. Pictures of all kinds can be used in a multiplicity of ways, as show drill, communication games, understanding, ornamentation, prediction, and discussion. One of the most appropriate uses for pictures is in the presenting and the checking of the meaning. ${ }^{12}$

Teacher also uses game to teach English learning in group or every person. The game is properly organized, and to act as an intermediary between learners and the teacher. Games also help the teacher to create contexts in which the language is useful and meaningful. ${ }^{13}$ The kinds of game for learning language is matching game, board game and $\mathrm{g}$ The game language for the deaf student is card game to interact and giving understanding the English Language.

\footnotetext{
${ }^{7}$ Observation at SLB Pertiwi, Ponorogo, on October 10 th 2017.

${ }^{8}$ Marc Marschark, Harry G. Lang and John A. Albertini, Educating Deaf Students from Research to Pratice, (New York: Oxford University Press, 2002), 166.

${ }^{9}$ Interview with English teacher at SLB Pertiwi, Ponorogo, on February 1 th 2018.

${ }_{10}$ Marc Marschark,et.al., Don't Assume Deaf Students are Visual Learners , (Online), 2016,(http://crossmark.crossmef.org/dialog/?doi=10.1007/s10882-016-9494-0\&domain=pdf, accessed on December 15 th 2017)

11 Ibid.,

12 Jeremy Harmer, The Practice of English Language Teaching, Third Edition (San Francisco: Longman, 2007), 134-135.

${ }^{13}$ Adrew Wright, David Betterdge and Michael Buckby, Game for Language Learning, Third Edition. (New York: Cambridge University Press, 2005), 3.
} 
The card is useful for matching activities, where students have to find another student in the class with a similar card or one that has the answer to the question on his or her card. The student can each be given word cards to hold in front of them and then be asked to move around until students form a line where all the cards together form a question or a sentence. ${ }^{14}$

The card game is one of the kinds of education game. Card game usually offers the fascinating challenges that the player may ever encounter. During the course of play, the player uses strategy, memory, cunning, and a whole host of other qualities to put together the best hand possible (or to bluff with the worst hand out there). ${ }^{15}$ The card game will help deaf students in understanding the English language by using pictures and game. By relaxing condition, the student can input the material of the English language easily.

Generally, the deaf students need more time to develop their brain than normal children because of students' environment is not support on their development. Their input is lower than normal children in the learning process. So, teachers have to use teaching method which focuses on motor activity to improve their communication and the mental. TPR is a language teaching method built around the coordination of speech and action; it attempts to teach language through physical (motor) activity. ${ }^{16} \mathrm{TPR}$ is right-brain learning. The TPR classroom, then, was a great deal of listening and acting. ${ }^{17}$ The students are understood and response what the teacher instructs attentively. This method helps the teacher to improve student activeness in the learning process.

Based on the explanation, the researcher wants to portray card game and total physical response (TPR) method to improve deaf students' English achievement at SLB-B Pertiwi Ponorogo.

\section{METHODS}

In this research,, the researcher applied Classroom action research.This research intended to improve student's skill in English class and their activeness in teaching-learning process by card game and total physical response (TPR) at SLB-B Pertiwi Ponorogo. Ebbutt asserts that action research as a systematic study that combines action and reflection with the intention of improving practice. ${ }^{18}$ It helps researcher to get solution for improving students' achievement. ZuberSkerritt asserts that 'the aims of any action research project or program are to bring about practical improvement, innovation, change or development of social practice, and the practitioners' better understanding of their practices'. ${ }^{19}$ Classroom action research involves teacher in their classroom. It also involves

\footnotetext{
14 Ibid., 140-141.

15 Barry Rigal, Card Game for Dummies (Canada: Willey Publishing Inc, 2005), 1.

${ }^{16}$ Jack C. Richards and Theodore S. Rodgers, Approach and Methods in Language Teaching (United of state America: Cambidge University Press, 1999), 87.

${ }^{17}$ Cantoni, Gina P, Using TPR-Storytelling To Develop Fluency and Literacy in Native American Languages ( US: Educational Resources Information Center (ERIC), 1999), 54.

18 Louis Cohence, Research Methods In Education (New York: Taylor\& Francis e-Library,

19 Ibid,.
} 2007), 298. 
groups of teachers examining common issues. The aim of this action research is to improve classroom practice or to improve practices in the school. ${ }^{20}$ It implied to this research to improving students' English achievement.

According to Kemmis and McTaggart, who are major authors in this field, AR typically involves four broad phases in a cycle of research. The first cycle may become a continuing, or iterative, spiral of cycles which recur until the action researcher has achieved a satisfactory outcome and the research time to stop. ${ }^{21}$ the procedure of the classroom Action Research (CAR) covers fourth components, there are as plan, ,action, observation and reflection. The second data is quantitative by calculating the students' answers of multiple choice test and written test. The average score of the test and percentages of students score wether they achieve the minimum mastery criterion (KKM) or not through the formula. The data from test from test was analyzed by using calculating the mean the formula: 22

$$
M x=\frac{\sum f x}{n}
$$

Note:

X: Mean

$\sum$ : Sum The score

$\mathrm{n}$ : Total Numbered if the student

f: Frequently

X: Total Score

\footnotetext{
2010), 515.

${ }^{20}$ Donald Ary, et al, Introduction to Research in Education (Canada: Nelson Education, Ltd,

21 Anne Burns, Doing Action Research in English Language Teaching: A Guide for Practitioners( New York: Routledge, 2010),9.

22 Retno Widyaningrum, Statistik Pendidikan ( Ponorogo: STAIN PO Press, 2007), 20-49.
} 
BL'TALL (IENGLISH IANGUAGE 'TEACHING, APPIIEI) LINGUISTICS

Available online at https:/ /jurnal.iainponorogo.ac.id/index.php/eltall

It is also analyzed by using percentage as follows

$P=\frac{f}{n} \times 100 \%$

Note:

P: Percentage

f: Frequency of answer

$\mathrm{n}$ : The number of respondent

\section{FINDINGS}

\section{Cycle 1}

The descriptions of the classroom action research process of each cycle follow:

\section{a. Planning}

For the first cycle, the researcher planned everything that needed for the researcher. Based on the observation in teaching-learning process, the researcher prepared treatment in improving students' vocabulary and writing skill of eleventh grade. The activities were done in these method points as follows:

1) Make a lesson plan based on the theme.

The teacher made lesson plan as the foundation for teaching-learning process. The teacher prepared subject matter, manage time, choosing of determining of the evaluation system, determine of study source, prepare the tools to support teaching learning process etc. The researcher prepared the lesson plan for the first cycle with "Make a Plan " as the theme.

2) Prepare the material

The material used was the dialogue text about " activities". Besides that, the researcher gives the future tenses material. It was copied as many as 6 pieces for students' text and students' worksheet.

3) The researcher prepared the research instruments

4) The teacher made evaluation instruments to know students' development such as

a. Observation sheet which would be used in observing the research.

b. Field note which would be used to note the situation when students do the activity.

c. The teacher gave evaluation formed written and multiple choice assignment. This assignment worked by each student. 


\section{b. Acting}

For the third meeting, the researcher did some activities. The researcher came into the classroom and ascertained all students watch the researcher in front of the class. Then the researcher greeted by using oral language clearly. The researcher gave explanation about activities.the researcher ask to give some the example of the activities. Students rewrote the dialogue on the whiteboard and translate every word together. The researcher explained the picture and the vocabularies of the activities. The researcher ask to repeated the vocabularies by observing the researcher which use oral language.

The resesrcher explained the future tense one by one the formation of the future tense. The researcher ask to student to make the example of the sentence by using future tense on the whiteboard. The reseacher asked to make a grup which conducted 2 students and matched the picture card and word card. The time to work was 8 minutes. If the grup was finished, the researcher asked to student rised their hand and submitted their worksheet. The researcher reflecting the students' working.

The researcher gave a written test about future tense. The times was 10 minutes. After that, the researcher giving multiple choice test about the material of the day. The time was 20 minutes. The researcher reviewing about all material which would be teach to students that day.Then, the researcher ascertained students to watch the researcher and then the researcher greeted to students to close the teaching-learning in the classroom. (look appendix 1)

\section{c. Observing}

During in the classroom, the researcher observe and made some notes about class situation and student activeness during the teaching-learning process. The researcher got the result of the students achievement as their comprehension of the material and activeness in learning writing and vocabulary using TPR method and card game. The result of observation in the first cycle explained as follows:

\section{1) Observation sheet}

Table 4.1

Result of The Observation sheet in Cycle 1

\begin{tabular}{|l|l|c|c|c|}
\hline No & \multicolumn{1}{|c|}{ Aspect of being observed } & Yes & No & Notify \\
\hline 1 & writing activities & & $\checkmark$ & \\
\hline 2 & vocabularies activities & & & \\
\hline 3 & discussion with the pair & & & \\
\hline 4 & the class is active & & $\checkmark$ & \\
\hline 5 & $\begin{array}{l}\text { Following the teaching-learning } \\
\text { process well }\end{array}$ & & & \\
\hline 6 & getting the passiveness & & & \\
\hline
\end{tabular}

The researcher found that the students response on instruction to make a pair for discussing the material. Students also see the students' explanation during 
Available online at https:/ /jurnal.iainponorogo.ac.id/index.php/eltall

teaching process but they did not give feedback to get understanding the material. In the cycle 1, the researcher found that students' vocabulary is limited. So, the classroom was not active to ask the answer to the material.

In another side, the researcher found the result of the observation in cycle 1 in the following:

Table 4.2

The Result of Students' Activeness Observation in Cycle 1

\begin{tabular}{|l|l|c|l|}
\hline \multirow{2}{*}{ No } & \multicolumn{1}{|c|}{ Name } & \multicolumn{2}{c|}{$\begin{array}{c}\text { Aspect of } \\
\text { Variable }\end{array}$} \\
\hline & & A & P \\
\hline 1 & Dicky Cahyo Gumelar & $\checkmark$ & \\
\hline 2 & Muhammad Faisal Amin & & $\checkmark$ \\
\hline 3 & Niamul Tamami & $\checkmark$ & \\
\hline 4 & Rifa Bela Rafsanjani & & $\checkmark$ \\
\hline 5 & Safitri & & $\checkmark$ \\
\hline 6 & Subekti Lulus Raharjo & & $\checkmark$ \\
\hline
\end{tabular}

Notes:

A: activeness: students are smart and fast response to doing teacher's instruction in the learning process.

P: Participate: students follow another student without have an idea.

Based on table 4.1, the researcher found that the participation of the student was low. It provided that 2 of 4 students were active during learning process.

\section{2) Test}

The researcher measured students' achievement used multiple choice test about the activities. The teacher asks the students to answer by choosing one of the multiple answers. The KKM is 70. If the result of the test is same or up to 70, the student was achieved. On the other way, If students'score is under to 70, the student was not achieved.

Table 4.3.

The Test Result of Test in Cycle 1

\begin{tabular}{|c|c|c|c|c|}
\hline \multirow{2}{*}{ NO } & \multirow{2}{*}{ NAME } & \multicolumn{2}{|c|}{ SCORE } & \multirow{2}{*}{ Note } \\
\hline & & KKM & SCORE & \\
\hline 1 & Dicky Cahyo Gumelar & 70 & 96 & Achieve \\
\hline 2 & $\begin{array}{l}\text { Muhammad Faisal } \\
\text { Amin }\end{array}$ & 70 & 80 & $\overline{\text { Achieve }}$ \\
\hline 3 & Niamul Tamami & 70 & 76 & Achieve \\
\hline 4 & Rifa Bela Rafsanjani & 70 & 66 & $\begin{array}{l}\text { Not } \\
\text { Achieve }\end{array}$ \\
\hline 5 & Safitri & 70 & 73 & Achieve \\
\hline 6 & Subekti Lulus Raharjo & 70 & 63 & $\begin{array}{l}\text { Not } \\
\text { Achieve }\end{array}$ \\
\hline & Total Finish & & 454 & 4 \\
\hline & Percentage & & & $66,67 \%$ \\
\hline
\end{tabular}


In table 4.3, the researcher found that 2 of 6 students are not achieving because they get a score below the KKM. So, the researcher has to improve students' skill to get score more than KKM.

\section{d. Reflection}

Based on the observation in the class, the student still confused about what would they do in class. They always do not to pay attention the teacher to know teacher's instruction. Automatically, the class was passive because student have limited vocabulary to understand the english language. So, the teacher need to guide student one by one for understand the material and vocabularies.

Based on the table above, it can be state that student progress record increased when taught by using TPR method and card game in cycle one. The result of observation on students' activeness and participate did not show maximal score. The evaluation result of students' vocabulary was poor. 2 of 6 students were active in learning process, 4 studets were participate but they have achievement. So, any students still not yet success. Teacher should monitor students' discussion intensively and give clearly reinforcement for the better result. Besides that, There were 3 students who got more than 70 and 3 students who got under 70 . It means that the students' progress record is under the criteria of succes. So, the researcher want continues to the cycle 2

\section{Cycle 2}

\section{a. Planning}

In this stage, the researcher planned a better planning to solve the problems in the previous meeting. The meeting in the cycle was one meeting. The activities were same with the first cycle, the differences than cycle 1 is giving attention and explanation for every student. Besides that, the students ask to give instruction so that students focuss on the material. The activities was explain in the following:

1) Make a lesson plan based on the theme.

The teacher made lesson plan as the foundation in teaching learning process. The teacher prepared subject matter, manage time, choosing of determining of the evaluation system, determine of study source, prepare the tools to support teaching learning process etc. The researcher prepared the lesson plan for the first cycle with "Make a Plan " as the theme (look the appendix 1)

2) Prepare the material

The material used was the dialogue text about "activities" and for the next material is future tense. it was copied as many as 6 pieces for students' text and students' worksheet.

3) The researcher prepared the research instruments

4) The teacher made evaluation instruments to know students' development such as

a. Observation sheet which would be used in observing the research.

b. Field note which would be used to note the situation when students do the activity.

c. The teacher gave evaluation formed written and multiple choice assignment. This assignment worked by each students. 


\section{b. Acting}

For the third meeting, the researcher did some activities. The researcher came into the classroom and ascertained all students watch the researcher in front of the class. Then the researcher greeted by using oral language clearly. The researcher gave explanation about the activities. The researcher ask to give some the example of the activities. Students rewrote the dialogue on the whiteboard and translate every word together. The researcher explained the picture and the vocabularies of the activities. The researcher ask to repeated the vocabularies by observing the researcher which use oral language.

The resesrcher explained the future tense clearly. The researcher ask to student to make the example of the sentence by using future tense on the whiteboard. The reseacher asked to make a grup which conducted 2 students and matched the picture card and word card. The time to work was 8 minutes. If the grup was finished, the researcher asked to student rised their hand and submitted their worksheet. The researcher reflecting the students' working.

The researcher gave a written test about future tense. The times was 10 minutes. After that, the researcher giving multiple choice test about the material of the day. The time was 20 minutes. The researcher reviewing about all material which would be teach to students that day.Then, the researcher ascertained students to watch the researcher and then the researcher greeted to students to close the teaching-learning in the classroom. (look appendix 2)

\section{c. Observing}

During in the clasroom, the researcher observe and made some notes about class situation and student activeness during the teaching-learning process. The researcher got the result of the students achievement as their comprehension of the material and activeness in learning writing and vocabulary using TPR method and card game. The result of observation in the second cycle explained as follows:

\section{1) Observation sheet}

Table 4.5

The Result of The Observation Sheet In Cycle 2

\begin{tabular}{|l|l|l|l|l|}
\hline No & \multicolumn{1}{|c|}{ Aspect of being observed } & Yes & No & Notify \\
\hline 1 & writing activities & & & \\
\hline 2 & vocabularies activities & & & \\
\hline 3 & discussion with the pair & & & \\
\hline 4 & the class is active & & & \\
\hline 5 & $\begin{array}{l}\text { Following the teaching learning } \\
\text { proccess well }\end{array}$ & & & \\
\hline 6 & getting the passiveness & & & \\
\hline
\end{tabular}

The table 4.5 explained that there are a changing in every aspect of the observation after revised the planning of the research. the researcher found that the classroom was more be active to the material of the lesson.

In another one, the observation of students' participation get improvement than cycle 1. It explains on the table 4.6. 
Table 4.6.

The Result of Students' Activeness Observation in Cycle 2

\begin{tabular}{|c|c|c|c|}
\hline \multirow[t]{2}{*}{ No } & \multirow[t]{2}{*}{ Name } & \multicolumn{2}{|c|}{$\begin{array}{l}\text { Aspect of } \\
\text { Variable }\end{array}$} \\
\hline & & $\mathbf{A}$ & $\mathbf{P}$ \\
\hline 1 & Dicky Cahyo Gumelar & $\checkmark$ & \\
\hline 2 & Muhammad Faisal Amin & $\checkmark$ & \\
\hline 3 & Niamul Tamami & $\checkmark$ & \\
\hline 4 & Rifa Bela Rafsanjani & $\checkmark$ & \\
\hline 5 & Safitri & $\checkmark$ & \\
\hline 6 & Subekti Lulus Raharjo & $\checkmark$ & \\
\hline
\end{tabular}

Notes:

A: Activeness : students are smart and fast response to doing teacher's instruction in learning process.

P: Participate : students are follow another student without have an idea.

2) Test

The researcher measured students' achievement used multiple choice test about the activities. The teacher ask the students to answer by choosing one of the multiple answer. The KKM is 70. If the result of the test is up or same in 70, the student was achieved. If the students get score under KKM criteria, the student was not achieved.

Table 4.7.

The Test Result of Cycle 2

\begin{tabular}{|c|c|c|c|c|}
\hline \multirow{2}{*}{ NO } & \multirow{2}{*}{ NAME } & \multicolumn{2}{|c|}{ SCORE } & \multirow{2}{*}{ NOTE } \\
\hline & & KKM & SCORE & \\
\hline 1 & $\begin{array}{c}\text { Dicky Cahyo } \\
\text { Gumelar }\end{array}$ & 70 & 100 & Achieve \\
\hline 2 & $\begin{array}{l}\text { Muhammad Faisal } \\
\text { Amin }\end{array}$ & 70 & 80 & Achieve \\
\hline 3 & Niamul Tamami & 70 & 100 & Achieve \\
\hline 4 & Rifa Bela Rafsanjani & 70 & 93 & Achieve \\
\hline 5 & Safitri & 70 & 83 & Achieve \\
\hline 6 & $\begin{array}{l}\text { Subekti Lulus } \\
\text { Raharjo }\end{array}$ & 70 & 73 & Achieve \\
\hline \multicolumn{3}{|c|}{ Total Finish } & 529 & 6 \\
\hline
\end{tabular}

Based on the table 1.7, it was better result than cycle 1 . All students get achieve and get the score up to the KKM . It means that the use TPR method and card game in learning english language was success to improve their brains'skill and English skill. 
BL'TALL (ENGLISH LANGUAGE 'TEACHING, APPIIEI) LINGUISTICS

AND II'TIRA'TURI)

Vol. 2 No. 1, 2021

Available online at https:/ /jurnal.iainponorogo.ac.id/index.php/eltall

\section{d. Reflection}

Based on the observation in the class, the students more anthusias to attend in learning process. They were active to answer the teacher's question when teacher tried to ask the example of the activites in the whiteboard. Besides that, There were 6 students who got more than 70. It means that the students' were succes by getting score more than KKM.

\section{DISCUSSION}

After the data had been collected, the research analyzed the data. Analysis data is the process of interpreting data which has purpose to manage the information as its functions till has the correct meaning with the suitable purpose of the study. ${ }^{23}$ Besides that, analysis data is break the data into manageable units, and discovering what is important and what is to be learned, and the data obtained from the result or responses from teaching activities by using TPR method and card game. The results of analyzing was to see whether the implementation of TPR method and card game is successful or not. So,the decision is made whether the implementation or continue the next cycle.

The data from the test is analyzed by using calculating the mean, the formula is. $^{24}$

$M x=\frac{\sum f x}{n}$

Note:

$\mathrm{X}$ : Mean

$\sum$ : Sum The score

$\mathrm{n}$ : Total Numbered if the student

f: Frequently

$\mathrm{X}$ : Total Score

It is also analyzed by using percentage as follows:

$P=\frac{f}{n} \times 100 \%$

Note:

P: Percentage

f: Frequency of answer

$\mathrm{n}$ : The number of respondents

To interpret students' score, the researcher used ordinal scale as the measurement tool to determine students' vocabulary skill. The criteria of students's score as follows:

90-100 = very good

80-89 = Good

$70-79=$ Fair

$60-69=$ low $/$ remedial

${ }^{23}$ Prof. Dr. H. Wina Sanjaya, M. Pd, Penelitian Tindakan Kelas (Jakarta: Kencana Prenada Group, 2009) 26.

${ }^{24}$ Retno Widyaningrum, Statistik Pendidikan ( Ponorogo: Stain Ponorogo Press, 2007), 49. 
50-59 = remedial

Formula of Mastery Learning :

Mastery learning

$=\underline{\text { number of students who achievement KKM }} \times 100$

Number of students

The criteria of students'vocabulary at eleventh gradeof SLB-B Pertiwi is said imptove if the mean of students in the second cycle is higher than the mean score of students in the first cycle and soon.

The researcher conducts the research in two cycles. By using TPR Method and card game, the research's result had established that there are a significance improvement in students' activeness and achievement. It can be seen in diagram below, as follow:

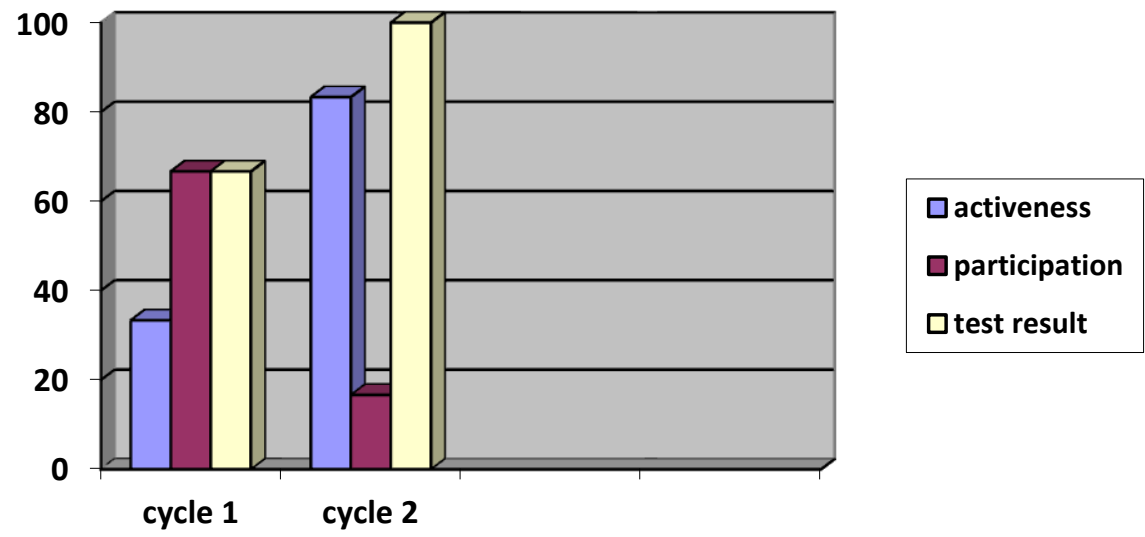

Diagram 5.1

The Percentage of Students Activeness and Achievement

\section{Sudents' Activeness}

Based on the responses' students in learning process during in two cycles, the researcher find out the improvement in the students activeness. It can be seen in a table below :

Table 4.13

The Student Activeness in Cycle 1 and Cycle 2

\begin{tabular}{|l|l|l|l|l|}
\hline \multirow{2}{*}{ Cycle } & \multicolumn{2}{|c|}{ Students' Activeness } & \multicolumn{2}{c|}{ Students' Participation } \\
\cline { 2 - 5 } & Students & Percentage & Students & Percentage \\
\hline Cycle 1 & 2 & $33,33 \%$ & 4 & $66,67 \%$ \\
\hline Cycle 2 & 4 & $83,33 \%$ & 1 & $16,67 \%$ \\
\hline
\end{tabular}

In table 1.9, the researcher found that there are 2 student are active and 4 student are participate in cycle 1 . The students's activeness is $33 \%$ and the students' participation is $66 \%$. In cycle 2, the researcher found 5 students are active in the class. The percentage of students activeness in cycle 2 is $83,33 \%$. It proved that the students' activeness is rising from 33\% to $83,33 \%$.

2. Students'Achievement

The researcher also also observes students' achievement bu using multiple choice test. Based on th students achievement, the researcher find out that there 
are $66 \%$ of students who passed in the cycle 1 and the amount of passed student in the cycle 2 increase well enough become $100 \%$. In can be explained in the table as follows:

Table1.4.14.

The Students'Achievement in Cycle I and Cycle II

\begin{tabular}{|c|c|c|}
\hline \multirow{2}{*}{ Cycle } & \multicolumn{2}{|c|}{ Students'Achievement } \\
\cline { 2 - 3 } & $\begin{array}{c}\text { Total of } \\
\text { Students }\end{array}$ & Percentage \\
\hline Cycle 1 & 4 & $66,67 \%$ \\
\hline Cycle 2 & 6 & $100 \%$ \\
\hline
\end{tabular}

It also provided that there was improvement from cycle 1 to cycle 2 in the criteria result of vocabulary test. The researcher found two students got good very good score, two students got good score and two students got fair score in cycle one. The other one, there are three students got very good score, two students got good score and one students got fair score.

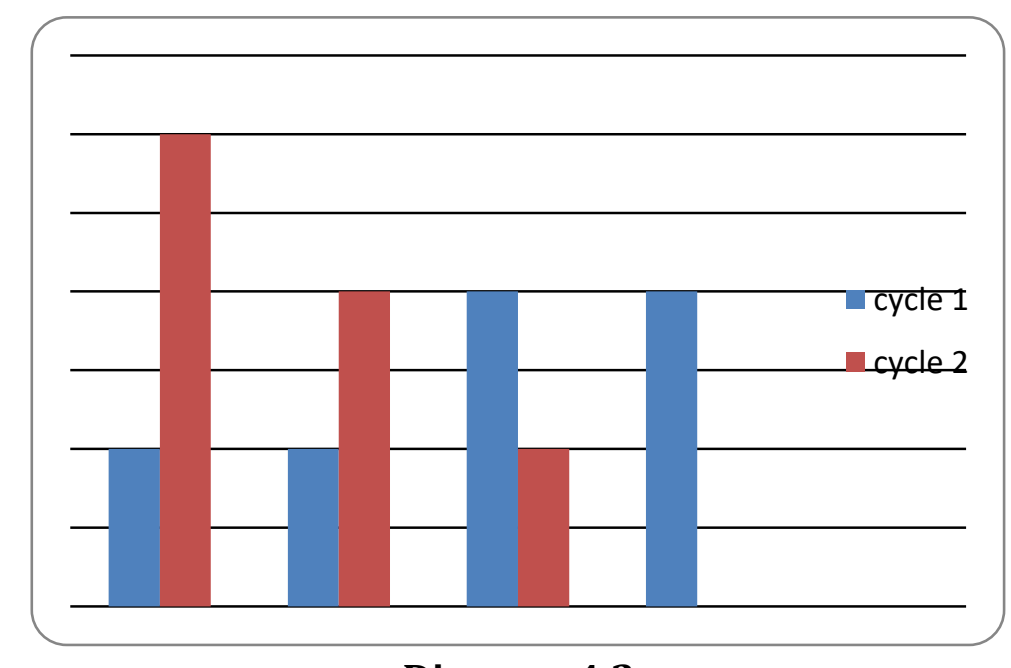

Diagram 4.2

The Result of vocabulary Test Based on Score Criteria

The researcher concluded that the use of TPR method and was able to improve the students vocabulary and writing achievement for eleventh grade students of SLB-B Pertiwi Ponorogo.

It supports that the history of the total physical response based on premise that the human brain has biological program for acquiring any natural language on the earth-including the sign language of the deaf. The process is visible when the researcher observes how infants internalize their first language. It looks to the way that children learn their native language. ${ }^{25}$

${ }^{25}$ Nining Pujiningsih, “Improving Students'English vocabulary by Using Total Physical Response”, ( Thesis, Sebelas Maret University, Surakarta,2010) , 26. 
In another one, games are important in teaching vocabulary because they highlight the necessary and important word to achieve the objectives of the game. $^{26}$ Besides that, games create a fun and relaxed atmosphere where young learners could learn fast and retain word better. ${ }^{27}$ Vernon also argued that games are an effective tool to teach vocabulary to young learner. ${ }^{28}$ Children participate and pay more attention because they enjoy themselves and the classroom and feel and doo better during and after the game.repeetation will be less boring and fun for children to which consolidates their lesrning of new words.

From the action in cycle 1 and cycle 2, the researcher found the strength and weakness of the TPR method and card game.

a. The Strengthness of Card Game and Total Physical Response (TPR) method

1) Card Game

a) Student more actively to understanding the material especially vocabularies by using picture media.

b) Students are enthusiastic to doing the game and discus with other students about the vocabularies.

c) The card game help students to remember the vocabularies easily.

2) Total Physical Response (TPR) method

a) The students more focus on teacher's instruction and do it quickly.

b) the students always give active response during teaching-learning process.

b. The Weakness of Card Game and Total physical response ( TPR) methc '

On applying total physical response(TPR) method, the researcher fou the student sometimes confuse when the teacher give instruction in fast speaking. So, the students can not to response the instruction correctly.

In other side, on applying card game, the students more focus on time of game. They do not correct their worksheet before they submit to the teacher.

\section{CONCLUSION AND SUGGESTION}

According to the research result, the use of card game and total physical response ( TPR) method at SLB-B Pertiwi Ponorogo can improve deaf students' English Achievement in acdemin year 2017/2018. The result of students' activeness showed at $33,33 \%$ to $83,33 \%$ at second cycle. In another one, the result of this research showed that the result of students'achievement on vocabulary is $66,67 \%$ at first cycle and $100 \%$ at second cycle. It means that the result of cycle 1 and cycle 2 have improvement significantly.

${ }^{26}$ Sahar Ameer Bakhsh, Using Games as a Tool in Teaching Vocabulary to Young Learners, (Online),Vol. 9, No. 7, 2016,(http://dx.doi.org/10.5539/elt.v9n7p120, accessed on December 30th 2017), 123.

27 Huyen N and Nga K. Learning vocabulary Through Games. Asian EFL Journal, 2003, 5.

28 Vernon, S. The Benefits of Using Games, Retrived June 20 th 2014, 2009,(http:www.english.com). 


\section{REFERENCES}

Peter Westwood. What Teachers Need Know About Teaching Methods. Australia: ACER Press. 2008.

Douglas Brown. Principles of Language Learning and Teaching. Fifth Edition. San Fransisco : Longman. 2007.

Marc Marschack and Praticia Elizabeth Spencer. The Oxford Handbook of Deaf Studies, Language, and Education. Vol.2. New York : Oxford University Press. 2010.

Jenny Frouded. Making Sense in Sign : A Lifeline for a Deaf Child. Britain : Cromwell press. Ltd. 2003.

Tammy Gallion. Improving Vocabulary Comprehension for Deaf or Hard of Hearing Students. Marshal University Press: Marshal University Scholar. 2016.

Arthur M. Glenberg and Michael P. Kaschak."The Body's Contribution To Language". In The Psychology of Learning and Motivation, ed. Brian H. Ross. United Stated of America : Academic Press. 2003.

Observation at SLB Pertiwi, Ponorogo, on October 10 th 2017.

Marc Marschark, Harry G. Lang and John A. Albertini, Educating Deaf Students from Research to Pratice, (New York: Oxford University Press, 2002), 166.

Interview with English teacher at SLB Pertiwi, Ponorogo, on February 1 th 2018.

Marc Marschark,et.al., Don't Assume Deaf Students are Visual Learners, (Online), 2016,(http://crossmark.crossmef.org/dialog/?doi=10.1007/s10882016-9494-0\&domain=pdf, accessed on December 15 th 2017)

Jeremy Harmer, The Practice of English Language Teaching, Third Edition (San Francisco: Longman, 2007), 134-135.

Adrew Wright, David Betterdge and Michael Buckby, Game for Language Learning, Third Edition. (New York: Cambridge University Press, 2005), 3.

1.

Barry Rigal, Card Game for Dummies (Canada: Willey Publishing Inc, 2005),

Jack C. Richards and Theodore S. Rodgers, Approach and Methods in Language Teaching (United of state America: Cambidge University Press, 1999), 87.

Cantoni, Gina P, Using TPR-Storytelling To Develop Fluency and Literacy in Native American Languages ( US: Educational Resources Information Center (ERIC), 1999), 54.

Susan Gregory, Juliet Bhisop and Lesley Sheldon, Deaf Young People and Their Families: Developing Understanding(New York : Cambridge university Press, 1995), 9.

Marc Marschark, Raising and Educating A Deaf Chlidren (United Stated of America : Oxford University Press, 1997),12.

Jenny Froude, Making Sense in Sign: A Lifeline for a Deaf Child (Britain: Cromwell Press.Ltd, 2003), 26. 
Marc Marschark, Harry G. Lang and John A. Albertini, Educating Deaf Students from Research to Pratice, (New York: Oxford University Press, 2002), 5.

Marschark, Harry G. Lang and John A. Albertini, Educating Deaf Students from Research to Pratice, (New York: Oxford University Press, 2002),76.

Lani Florian and John Hegarty, ICT and Special Educational Needs: A Tool for Inclusion (Britain: Open University Press, xii.

Marc Marschark, Harry G. Lang and John A. Albertini, Educating Deaf Students from Research to Pratice, (New York: Oxford University Press, 2002), $\mathrm{x}$.

Lani Florian and John Hegarty, ICT and Special Educational Needs: A Tool for Inclusion Britain: Open University Press, 119.

Douglas Brown, Principles of Language Learning and Teaching, Fifth Edition ( San Fransisco : Longman, 2007), 129.

Marc Marschark,et.al., Don't Assume Deaf Students are Visual Learners ,(Online), 2016,(http://crossmark.crossmef.org/dialog/?doi=10.1007/s10882016-9494-0\&domain=pdf, accessed on December 15 th 2017)

Jack C. Richards and Theodore S. Rodgers, Approach and Methods in Language Teaching (United of state America: Cambidge University, 1999), 87.

H.Douglas Brown, Teaching by Principles : An Interactive Ap,proach to Language Pedagogy, Second Edition( New York:Addison Wesley Longman Limited,2001) 29.

Teaching Children Using a Total Physical Response (TPR) Method: Rethinking (online) Handoyo Puji Widodo.(citeseerx.ist.psu.edu, accessed on December 6 th 2017).

Adrew Wright, David Betterdge and Michael Buckby Game for Language Learning, Third Edition. New York: Cambridge University Press. 2005.

Prof. Dr. H. Wina Sanjaya. M. Pd. Penelitian Tindakan Kelas. Jakarta: Kencana Prenada Group. 2009.

Retno Widyaningrum. Statistik Pendidikan. Ponorogo: Stain Ponorogo Press. 2007.

Nining Pujiningsih. “Improving Students'English vocabulary by Using Total Physical Response”. Thesis, Sebelas Maret University, Surakarta,2010.

Sahar Ameer Bakhsh, Using Games as a Tool in Teaching Vocabulary to $\begin{array}{lllll}\text { Young Learners, } & \text { (Online).Vol. } & 9 . & \text { No. } & 7 .\end{array}$ (http://dx.doi.org/10.5539/elt.v9n7p120, accessed on December 30 2017. 2003.

Huyen N and Nga K. Learning vocabulary Through Games. Asian EFL Journal.

Vernon. S. The Benefits of Using Games. Retrived June 20 th 2014. 2009.(http:www.english.com). 